\title{
Cell Cycle Checkpoint Control Protein RAD9B
}

National Cancer Institute

\section{Source}

National Cancer Institute. Cell Cycle Checkpoint Control Protein RAD9B. NCI Thesaurus.

Code C106282.

Cell cycle checkpoint control protein RAD9B (426 aa, $48 \mathrm{kDa}$ ) is encoded by the human RAD9B gene. This protein is involved in the modulation of both cell cycle progression and DNA repair. 